\title{
Family type and ethnic differences in lifetime fertility in selected West African Countries
}

\author{
Bosede O. Oyinloye, Olusina S. Bamiwuye, Joseph A. Kupoluyi \& Bola L., Solanke
}

\author{
Department of Demography and Social Statistics \\ Obafemi Awolowo University, \\ Ile-Ife, Nigeria. \\ boseloye@yahoo.com
}

\begin{abstract}
This study examines the effect of family type and ethnic differences in lifetime fertility in three selected West African countries. Using the Demographic and Health Survey datasets of a weighted sample of 10,324 ever married women in Burkina Faso(20l0), 5,099 in the Gambia(20I3) and 20,014 in Nigeria(20I3), the mean children ever born was higher among Gourmatch ethnic group in Burkina Faso (4.45), Fula in Gambia (4.05) and Hausa/Fulani in Nigeria (4.68). Further analysis using Poisson Regression showed that lifetime fertility was significantly higher by $29 \%$ among the polygynous family in Burkina Faso, $46 \%$ in Gambia and $25 \%$ in Nigeria than among the monogamous family. Age at marriage, age at first birth, wealth status and educational attainment of women were significantly associated with lifetime fertility. Findings suggest that lifetime fertility will reduce if pro-natalists' attitude, poverty, age at first marriage and age at first birth could be properly addressed.
\end{abstract}

Keywords: Ethnicity, Family Type, Lifetime Fertility, Monogamous, Polygynous

\section{Introduction}

Lifetime Fertility (LF) which is also referred to as Total Fertility Rate (TFR) accounts for the total number of children that should be born to a woman if she survives or lives through the end of her childbearing years (CIA World Factbook, 20I2). The number of children ever born to a particular woman is a measure of her lifetime fertility experience up to the moment at which the data were collected (World Fertility Data, 2012). Although, there has been an overall decline in the world's fertility levels, however, this has not been the case for the developing nations, particularly in West Africa region. Fertility rates in Africa have declined significantly in the Northern and Southern Africa to about three children per woman; whereas, much higher fertility still persists in West Africa with at least five children born to a woman (Madsen, 20I5). High fertility has been linked to increasing poverty level, unemployment, starvation, costs of raising child, school drop-out, number of refugees, shortages of fresh water, global warming, risk of mortality in maternal, infancy and early childhood, urbanization, low per capital income, among others. As a result of this, lowering fertility has been a major policy concern in many West Africa countries (Madsen, 2015).

Many policies and programmes that have been formulated to control fertility levels majorly centered on family planning and the use of contraceptives. For instance, the Nigeria 2004 revised national policy on population was aimed at reducing population growth rate through fertility control by encouraging child spacing and the use of contraceptives. Also, the Nigerian Family Planning Blueprint (Scale-Up Plan) which was launched in 2014 was vested with the sole aim of addressing the existing gap in the provision of high-quality family planning services and the use of modern contraceptive by Nigerians of reproductive age. In 1979. Similarly, the government of Gambia established an explicit population policy that recommended the availability and delivery of family planning services within the maternal-child health system, as well as a community-based contraceptive distribution system in the process of being expanded to cover all of the Gambia (Taylor-Thomas, 1989).

Specifically, Nigeria, like many other developing countries, is characterized by high fertility, high unmet needs, and low contraceptive use. Despite public awareness of family planning in Nigeria particularly among the married women, the country's contraceptive prevalence only increased by $2.1 \%$ between 2009 and 2013 (United Nations Population Division, 2009; National Population Commission [NPC] and ICF International, 20I4). According to the 2013 Nigeria Demographic and Health Survey, contraceptive prevalence rate stands at $11 \%$ while modern contraceptive use is $10 \%$ among married women. Also, analysis of fertility shows that the TFRs 
of the country have experienced a very slow decline. Estimates of total fertility rate per woman were 5.7 in 2003, 5.7 in 2008 and 5.5 in 2013 (NPC and ICF International, 20l4). These estimates have shown why the country is lagging behind in bringing down TFR below 5 children (Reed and Mberu, 20l4).

Gambia's population according to the 2013 national census was estimated at 1.9 million with an annual growth rate of $3.3 \%$ (The Gambia Bureau of Statistics [GBoS] and ICF International (20I4). Although, the population of Gambia has shown a decline over time; but like many other sub-Saharan African countries, Gambia is characterized by a population age-structure that is heavily skewed towards the youth. The population under 15 years in 2013 was estimated at approximately $43 \%$ compared to $41.6 \%$ in 1973 (The Gambia Bureau of Statistics [GBoS] and ICF International (20/4). In addition, Gambia is known to have one of the highest total fertility rates in the world with TFR of 6.04 in 1993, but now have an estimate of 5.75 (World Bank Indicator, 2013). The current estimated total fertility rate according to the 2013 Gambia Demographic and Health Survey was 5.6 children per woman. Also, according to the survey, the contraceptive use among married women aged $15-49$ years was $9 \%$ out of which $8 \%$ used the modern method and $1 \%$ used traditional methods.

In Burkina Faso, the population has experienced a considerable decline from 6.8 births per woman in 1988 to 5.9 births per woman in 2003. However, fertility remains high in the country (Burkina Faso Standard DHS, 2003). According to World Bank (20II) the average annual growth rate of the country is 2.4 percent with nearly half of the population as a youth. A wide difference exists between the fertility of women in the lowest wealth quintiles (6.4 births per woman) which nearly double those in the highest wealth quintile (3.6 births per woman). Similarly, the women with no educational background that dwells in the rural residences are having more than 6 children per woman (Burkina Faso Standard DHS, 2003). Current contraceptive use has slowly increased from 4 percent among married women in 1993 to 9 percent in 2003 and to 13 percent in 2006 (Burkina Faso Multiple Indicator Cluster Surveys and Burkina Faso Standard DHS, 2003).

\section{Literature review}

Studies in the developing and developed countries have linked lifetime fertility to women's low socioeconomic status and empowerment (Bongaarts, 2002; El-Ghannam, 2005; Bbaale and Mpuga, 20II; Dribe et al, 20I4, Upadhyay, 20I4). It is generally assumed that women with low economic status give birth to a higher number of children than those with higher status (Hyatt and Milne, 1993; Gwatkin et al, 2007). However, this assertion may not necessarily hold in some societal contexts. For instance, in a state of economic crisis, lower number of children have been reported among women facing hardship or poverty (Egero, 1996). Equally, in some Asian countries, poorer women have reportedly demanded a lower number of children as compared with their rich counterparts (Odusola, 2002; Alonzo et al, 2004; Orbeta, 2005). Another study carried out in Nigeria during the period of an economic crisis revealed that lower fertility preferences were observed among women. It was noted that poverty had affected their economic opportunities and as such could not fund many children (Odusola, 2002). Other socioeconomic and demographic factors affecting fertility that have been revealed by previous findings include age at marriage (Acharya, 20l0; Nahar et al., 20I3), age at first birth (Oyefara, 20II), religion (Chamie, 1977; Chaudhury, 1984; LeCostaouec, 2006; Akintunde et al, 20l3), education (Basu, 2002; Cleland, 2002; Martin, 1995), culture (Komurembe, 20II), income/wealth status (Skirbekk, 2008; Institute of Family Studies, 20/3).

Behavioural factors that affects lifetime fertility include unmet need for contraception (Casterline and Sinding, 2000; Asamoah et al, 2013), preference for large families (Becker, 1960), sex preference (Kumar and Kshatriya, 2013; Rai et al, 2014; Adebowale and Palamuleni, 20I5), community institutions that favour child-bearing (Makinwa-Adebusoye, 200I), pressure or influence from family/relatives/kinsmen (Mase and lan, 2003), decision-making autonomy (Hindin, 2000; Upadhyay and Karasek, 20l0), and net economic benefits of higher number of children (Merrick, 2002) among others. Mortality levels have also been found to play a key role in determining fertility (Caldwell et al, 1992; Fitaw et al., 2004). This is because it is often expected that women who have lost some children would want to give birth to more children and therefore, discourages the practice of contraception (Mturi, 1989; Sanderson, 200I). Yet, limited research has been done in West Africa to explain the effect of family type and ethnicity on lifetime fertility.

Available evidence has shown that fertility behavior of women may also be influenced by a range of cultural practices and behaviors. The type of family and ethnic identification are one of the ways to understand the complexity of the African societies. Studies have shown that individual's cultural attachment and identity may affect behavior including reproduction (Bauni et al, 2002; Nahmias, 2005; Satyajeet, 2005). The term ethnicity refers to the relationships between groups whose members consider themselves culturally distinctive (Eriksen, 1993). Ethnicity is also the basis of social organization 
in the traditional context and encompasses the beliefs and norms governing various life events (Gyimah, 2002). It distinguishes groupings of people who for historical events have come to see themselves as unique by their series of cultural makers (Fayehun and Omololu, 2007).

The common characteristics of African householdthey are mostly rural and patriarchal, give credence to lineage continuity, commonly polygyny and are not nuclear-embracing family type have implications on fertility outcomes of women (Makinwa- Adebusoye, 200I). In this type of setting, a woman's conscious effort to make cautious choices regarding the number of births is influenced by the existing norms and models that thrive in these social settings. This is much observed particularly where there is absence of formal social systems and a weak institution. As a result, people rely on their family and social networks for access to resources and other needs and will therefore not stray from their commonly shared values and norms in the community (Caldwell and Caldwell, 1987; Smith, 2004). In such cases, any change in a woman's reproductive performance is initiated not by the modern institutions, but from the prevailing relations and common norms peculiar to the family and community (Bongaarts, 2002).

Equally, most African societies are patriarchal systems characterized by gender inequality. These systems give men higher priority and right to control and make decisions regarding their family structure including the number of wives to marry. The subjective status of women in these social systems however, accords women a lower control over their fertility decisions and increases their burden of childbearing (Chege, 2005). Consequently, many of these societies are characterized by polygyny family structure (Therborn, 2006); and it is centred on the notion of excluding the situation of husband's shortage.

Polygyny is the act of an individual (usually a man) getting married to more than one wife concurrently (Barnes, 1970). Makinwa-Adebusoye (200I) reported that as at 1999, approximately $38 \%$ of married women in Nigeria were in polygyny marriages which made up of two or more wives. The author revealed that this kind of family setting is usually characterized by trend of early marriage and large family size. The 1999 Nigeria Demographic and Health Survey reported that about 36 percent of the currently married women are in polygyny households with 17 percent having two or more co-wives. Also, studies conducted during the periods of 1930 to 1950 showed that polygyny was peculiar in many African countries and it is the ideal for most African regions (Bell and Vogel, 1960; Chondoka, 1988). This, however, invariably increases the number of children that would be born to a man from more than one wife. Also, the assumption that many children command respect for a woman in a polygyny family setting increases a woman's quest for more children. These family settings and ethnic beliefs have an impact on the way of life of women including fertility outcomes.

In view of these, it is imperative to examine the role of family type and ethnicity on lifetime fertility in selected West African countries. This may give an insight into the factors responsible for the current increase in fertility that has persisted in the selected countries. Hence, this study seeks to examine the influence of family type and ethnic differences in the lifetime fertility in the three selected West African countries (Burkina Faso, Gambia, and Nigeria).

\section{Theoretical literature}

This study views fertility from two theoretical perspectives. According to the economic explanation of fertility performance, reproduction is determined by the couples' rational decision making Easterlin (1969). In this explanatory framework, reproduction is weighed alongside the corresponding satisfaction derived from it (Leibenstein, 1957 and Becker, 1960). The transition from an agrarian society to a modernized one stems up new forms of savings and investments that replace the initial purpose of having a higher number of children (Bongaarts, 2006). Thus, the cost of having an additional child is balanced against the expected social, economic and psychological benefits that would be derived from the child.

The second analytical framework is the social and cultural theories of fertility. Due to the value placed on the higher number of children in the most African societies, the socio-cultural theories on fertility was adopted to explain how fertility is determined by the prevailing culture which in turn affects the psychological attitude of man. Individual reproductive behaviours are receptive to social organizational characteristics, institutions, and patterns of social and economic interactions (David and Blake, 1956). In order words, demand for children is influenced by the norms and attitudes of the society. However, no single theory has fully defined fertility behaviour but from the two analytical frameworks, several socioeconomic and cultural factors such as marriage type, education, income, age at marriage, among others have been highlighted to affect the demand for children. It is upon these theories that this study builds on.

\section{Data and methods}

Data were sourced from the most recent DHSs of three countries selected in West Africa- 2010 Burkina 
Faso DHS, 2013 Gambia DHS, and 2013 Nigeria DHS. The selection was based on the high Total Fertility Rate (TFR $>5)$ that travails in those countries- Burkina Faso (5.7) Gambia (5.6) and Nigeria (5.5) - DHSs and availability of nationally representative and comparable data. For the purpose of this work, women with no children were excluded from the analysis processes. A weighted sample size of 10344,5 099, and 20014 ever married women aged 15-49 years who had had at least a birth in the five years preceding the survey and interviewed respectively, were analyzed.

\section{Sampling design}

\section{Burkina Faso}

The 2010 Burkina Faso Demographic and Health Survey (BFDHS) was a cross-sectional survey which collected a national-level data on population and health. The survey samples were drawn in two stages. The updated master sampling frame for Population and Housing Census was used in the first stage to select clusters. Systematic sampling with probability proportional to size was used to select 574 clusters (176 in urban and 398 in rural areas). Households were listed for the sampling frame from which households were selected with exception of one cluster in the Sahel region using a systematic sampling with equal probability in the second cluster (see Institut National de la Statistique et de la Démographie (INSD) et ICF International, 2012 for details). Out of 17,087 women age 15-49 years that were interviewed, a weighted sample size of 10344 ever-married women aged 15-49 years that had had at least a birth in the 5 years preceding the survey were obtained from the women data set and analyzed.

\section{Gambia}

The 2013 Gambia Demographic and Health Survey (GDHS) was a cross-sectional survey which collected population and health information. Administratively, Gambia is divided into eight Local Government Areas and districts. Each district (apart from Banjul) is subdivided into settlements. The EAs created during the 2003 census which made up of either a settlement, and a cluster; a small settlement, or part of a large settlement was used as the primary sampling units (PSUs). A stratified two-stage cluster sampling design was used. Stratification was done by dividing each LGA into urban and rural areas (apart from urban settlements of Banjul and Kanifing). A total of 28I EAs were selected from the I4 sampling strata identified in the first stage using probability proportional to the size and with independent selection in each sampling stratum. In the second stage, 25 households per EA were selected via equal probability systematic selection. All women age 15-49 who were usual household members or who spent the night before the survey in the selected households was eligible for individual interviews (details in the Gambia Bureau of Statistics (GBOS) and ICF International, 20/4). A weighted sample size of 5099 women aged 15-49 years that had had at least a birth in the 5 years preceding the survey and interviewed, were obtained from the women data set and analyzed.

\section{Nigeria}

The 2013 Nigerian Demographic and Health Survey (NDHS) was a cross-sectional nationally representative survey which collected information on population and health indicators at the national and state levels. Administratively, the country is divided into states, local government areas (LGAs), and localities. Each locality was subdivided into census enumeration areas (EAs). The DHS primary sampling unit also referred to as the cluster, was selected from the lists of enumeration areas (EAs) demarcated for the 2006 Population Census and used as the survey's sampling frame. A stratified three-stage cluster design containing 904 clusters; 372 in urban areas and 532 in rural areas was used. A representative sample of 40,680 households was selected for the survey, with a minimum target of 943 completed interviews per state (see National Population Commission (NPC) [Nigeria] and ICF International. 2014 for details). In this study, out of 38,948 women aged 15-49 who were interviewed, a weighted sample size of 20014 women aged I 5-49 years that had had at least a birth in the 5 years preceding the survey were obtained from the women data set and analyzed.

\section{Measurement of variables \\ Principal explanatory variables}

The principal explanatory variables were family type and ethnicity. On family type, single women were excluded while currently and formerly married women were reclassified as either in a polygyny family type or monogamy family type. A married woman who reported that her partner had more than a wife was classified as living in a polygyny family and represented by "I" and "0" otherwise. Also, classification on ethnicity was done based on the major ethnic groups in the selected countries while other minority groups were represented as "Others". 


\section{Control variables}

The control variables used in the study are variables which have been found to relate to the analysis of fertility as well as used as control variables in the multivariate analysis (Adhikari, 2010; Alonge and Ajala, 2013). They include age (15-24, 25-34, 35+), age at marriage (below 18, 18-24, 25+), age at first birth (below 18, 18-24, 25+), education (no education, primary, secondary + ), wealth status (poor, average and rich), residence (urban, rural) and religion (no religion, Christianity, Islam, Traditionalist). For household characteristics which are decision-making autonomy, a composite score was obtained from the three categories (health, large household purchase and visits to family/relatives) and a dichotomous variable was derived. Women who did not make solely or joint decisions with their husbands/partners were regarded as 'not involved' in decision making and were categorized as "I" and " 0 " otherwise. This classification was adopted from the DHSs. A composite score was also used to measure exposure to media. All the women that reported being exposed to watching television, listening to radio and reading newspaper were categorized as ' $\mathrm{l}$ ' and ' 0 ' otherwise.

\section{Outcome variable}

Lifetime fertility was used in this study as the outcome variable and was proxy by total number of children ever born (CEB). The DHSs captured information on CEB by asking each woman questions relating to fertility issues like number of sons and daughters living with her or elsewhere, including those delivered and died later.

\section{Data analysis}

Data were analyzed for the three countries separately using both descriptive and inferential statistics. Firstly, descriptive statistics were used to describe women aged 15-49 years by their individual and household characteristics. Secondly, the mean number of children born were derived in order to compare fertility differences across all women categories in the study. Lastly, at the multivariate level of analysis, we obtained models of Poisson Regression analysis to predict lifetime fertility based on the explanatory variables and on selected individual variables. Model I explained the unadjusted effects of the key explanatory variables (family type and ethnicity) on the outcome variable (Lifetime fertility). Model 2 presented the adjusted effects of family type and ethnicity on lifetime fertility while other variables were held constant. The Poisson Regression analysis was employed because the outcome variable was a count data and not continuous. Weighing factor provided by measure DHS was applied in the data management to account for oversampling of some sections of the population. The SVY command in STATA was applied to make it consider complex survey design in the analyses.

\section{Results \\ Univariate}

Table I presents information on the family type, ethnicity and other background statistics of evermarried women aged 15-49 years with at least a birth. Results reveal that polygyny family type is highest in Burkina Faso (42 percent) followed by Gambia (37 percent) and Nigeria (32 percent). Also, the analysis showed that majority of the women were from Mossi in Burkina Faso (5I percent), Mandinka/Jahanka in Gambia (33 percent) and from Hausa/Fulani in Nigeria (43 percent). Across the three countries under study, a large proportion of the women were age between 25-34 years while at least half of the women got married below 18 years of age. While more than half had their first birth between ages 18-24 years in Burkina Faso and Gambia, more than two-fifths (48\% percent) had their first birth between 18-24 years in Nigeria. Majority of the respondents were uneducated and were poor. This is also evident across the three countries. Four in ten persons were rural dwellers; Islam was the dominant religion in Burkina Faso and Nigeria while it was Christianity in Gambia. Information on underlying variables of lifetime fertility showed that almost all the women were exposed to media but were not involved in decision making. 
Table I: Percentage distribution of women by family type, ethnicity and individual characteristics.

\begin{tabular}{|c|c|c|c|}
\hline \multirow[b]{2}{*}{ VARIABLES } & \multirow[t]{2}{*}{$\begin{array}{c}\text { Burkina Faso } \\
n=10344\end{array}$} & \multirow[t]{2}{*}{$\begin{array}{l}\text { Gambia } \\
n=5099\end{array}$} & \multirow{2}{*}{$\begin{array}{l}\text { Nigeria } \\
n=200 \mid 4\end{array}$} \\
\hline & & & \\
\hline $\begin{array}{l}\text { Monogamy } \\
\text { Polygyny }\end{array}$ & $\begin{array}{ll}5926 & (58.5) \\
4207 & (41.5) \\
\end{array}$ & $\begin{array}{ll}3108 & (63.5) \\
1782 & (36.5) \\
\end{array}$ & $\begin{array}{ll}13200 & (86.1) \\
6197 & (31.9)\end{array}$ \\
\hline $\begin{array}{l}\text { Ethnicity } \\
\text { (Burkina Faso) } \\
\text { Fulfude/ Peul } \\
\text { Gourmatche } \\
\text { Mossi } \\
\text { Senoufo } \\
\text { Others }\end{array}$ & $\begin{array}{ll}983 & (9.5) \\
872 & (8.4) \\
5319 & (51.4) \\
457 & (4.5) \\
2713 & (26.2) \\
\end{array}$ & $\begin{array}{l}- \\
- \\
- \\
- \\
-\end{array}$ & $\begin{array}{l}- \\
- \\
- \\
- \\
-\end{array}$ \\
\hline $\begin{array}{l}\text { (Gambia) } \\
\text { Mandinka/ Jahanka } \\
\text { Wollof } \\
\text { Jola/ Karoninka } \\
\text { Fula/Tukulur/Lorobo } \\
\text { Serahuleh } \\
\text { Others }\end{array}$ & $\begin{array}{l}- \\
- \\
- \\
- \\
- \\
-\end{array}$ & $\begin{array}{ll}1682 & (33.0) \\
677 & (13.3) \\
458 & (9.0) \\
1213 & (23.8) \\
384 & (7.5) \\
685 & (13.4)\end{array}$ & $\begin{array}{l}- \\
- \\
- \\
- \\
- \\
-\end{array}$ \\
\hline $\begin{array}{l}\text { (Nigeria) } \\
\text { Hausa/Fulani } \\
\text { lgbo/lbo } \\
\text { Yoruba } \\
\text { Others } \\
\end{array}$ & $\begin{array}{l}- \\
- \\
- \\
-\end{array}$ & $\begin{array}{l}- \\
- \\
- \\
-\end{array}$ & $\begin{array}{ll}8611 & (43.0) \\
2102 & (10.5) \\
2421 & (12.1) \\
6880 & (34.4) \\
\end{array}$ \\
\hline $\begin{array}{l}\text { Age of respondents } \\
\text { I5-24 years } \\
25-34 \text { years } \\
35 \text { years }+\end{array}$ & $\begin{array}{ll}2955 & (28.6) \\
4763 & (46.0) \\
2626 & (25.4) \\
\end{array}$ & $\begin{array}{ll}\text { I } 329 & (26.1) \\
2499 & (49.0) \\
\text { I 27I } & (24.9) \\
\end{array}$ & $\begin{array}{l}4996 \\
9514 \\
5504 \\
\end{array}$ \\
\hline $\begin{array}{l}\text { Age at marriage } \\
<18 \text { years } \\
18-24 \text { years } \\
25 \text { years }+\end{array}$ & $\begin{array}{ll}6049 & (58.5) \\
4054 & (39.2) \\
241 & (2.33) \\
\end{array}$ & $\begin{array}{ll}2534 & (49.7) \\
2201 & (43.2) \\
364 & (7.1) \\
\end{array}$ & $\begin{array}{l}11691 \\
6601 \\
1722 \\
\end{array}$ \\
\hline $\begin{array}{l}\text { Age at first birth } \\
<18 \text { years } \\
18-24 \text { years } \\
25 \text { years }+\end{array}$ & $\begin{array}{ll}3411 & (33.0) \\
6381 & (6 I .7) \\
552 & (5.3) \\
\end{array}$ & $\begin{array}{ll}1694 & (33.2) \\
2854 & (56.0) \\
551 & (10.8) \\
\end{array}$ & $\begin{array}{l}7910 \\
9595 \\
2509 \\
\end{array}$ \\
\hline $\begin{array}{l}\text { Education } \\
\text { No education } \\
\text { Primary } \\
\text { Secondary and above }\end{array}$ & $\begin{array}{ll}8607 & (83.2) \\
1|4| & (11.0) \\
596 & (5.8) \\
\end{array}$ & $\begin{array}{ll}3039 & (59.6) \\
711 & (13.9) \\
1349 & (26.5) \\
\end{array}$ & $\begin{array}{l}9779 \\
3842 \\
6393\end{array}$ \\
\hline $\begin{array}{l}\text { Wealth status } \\
\text { Poor } \\
\text { Average } \\
\text { Rich }\end{array}$ & $\begin{array}{ll}4217 & (40.8) \\
2216 & (21.4) \\
3911 & (37.8) \\
\end{array}$ & $\begin{array}{ll}2072 & (40.6) \\
1032 & (20.3) \\
1995 & (39.1) \\
\end{array}$ & $\begin{array}{l}9180 \\
3749 \\
7085 \\
\end{array}$ \\
\hline $\begin{array}{l}\text { Residence } \\
\text { Urban } \\
\text { Rural } \\
\end{array}$ & $\begin{array}{ll}1911 & (18.5) \\
8433 & (81.5) \\
\end{array}$ & $\begin{array}{ll}2496 & (48.9) \\
2603 & (51.1) \\
\end{array}$ & $\begin{array}{l}7087 \\
12927 \\
\end{array}$ \\
\hline $\begin{array}{l}\text { Religion } \\
\text { No religion } \\
\text { Christianity } \\
\text { Islam } \\
\text { Traditionalists/Others }\end{array}$ & $\begin{array}{ll}127 & (1.2) \\
2797 & (27.0) \\
6584 & (63.7) \\
836 & (8.1)\end{array}$ & $\begin{array}{ll}4995 & (97.0) \\
102 & (2.0) \\
2 & (1.0)\end{array}$ & $\begin{array}{ll}7293 & (36.4) \\
12405 & (61.9) \\
316 & (1.7)\end{array}$ \\
\hline
\end{tabular}




\begin{tabular}{|c|c|c|c|c|c|c|}
\hline $\begin{array}{l}\text { Decision-making autonomy } \\
\text { Woman involved } \\
\text { Woman not involved }\end{array}$ & $\begin{array}{lll}1 & 11 \\
9 & 0213 \\
\end{array}$ & $\begin{array}{l}(11.0) \\
(89.0)\end{array}$ & $\begin{array}{l}1870 \\
3020 \\
\end{array}$ & $\begin{array}{l}(38.2) \\
(61.8)\end{array}$ & $\begin{array}{l}5625 \\
13772 \\
\end{array}$ & $\begin{array}{l}(29.0) \\
(71.0)\end{array}$ \\
\hline $\begin{array}{l}\text { Media exposure } \\
\text { Yes } \\
\text { No }\end{array}$ & $\begin{array}{l}7498 \\
2846\end{array}$ & $\begin{array}{l}(72.5) \\
(27.5)\end{array}$ & $\begin{array}{l}4576 \\
523\end{array}$ & $\begin{array}{l}(89.8) \\
(10.2)\end{array}$ & $\begin{array}{l}13391 \\
6613\end{array}$ & $\begin{array}{l}(66.9) \\
(33.1)\end{array}$ \\
\hline
\end{tabular}

Table 2 presents the weighted mean number of children ever born by family type and ethnicity. Results show that fertility was higher in a polygyny family type than in monogamy family settings. This is evident across the three countries under study. With respect to ethnicity, the result showed that mean
CEB was high across all ethnic groups in Burkina Faso and in Gambia with at least four children born to a woman. In Nigeria, mean CEB was highest among Hausa/Fulani women, followed by the Igbo/lbos while the lowest was among the Yoruba women.

Table 2: Mean differences of lifetime fertility by family type and ethnicity in Burkina Faso, Gambia, and Nigeria.

\begin{tabular}{|c|c|c|c|c|c|}
\hline $\begin{array}{l}\text { Explanatory } \\
\text { variables }\end{array}$ & Burkina Faso & $\begin{array}{l}\text { Explanatory } \\
\text { variables }\end{array}$ & Gambia & $\begin{array}{l}\text { Explanatory } \\
\text { variables }\end{array}$ & Nigeria \\
\hline & $\begin{array}{l}\text { Weighted } \\
\text { Mean (N) }\end{array}$ & & $\begin{array}{l}\text { Weighted Mean } \\
\text { (N) }\end{array}$ & & $\begin{array}{l}\text { Weighted } \\
\text { Mean (N) }\end{array}$ \\
\hline $\begin{array}{l}\text { Family type } \\
\text { Monogamy } \\
\text { Polygyny }\end{array}$ & $\begin{array}{l}3.60(5 \text { 926) } \\
4.65(4207)\end{array}$ & $\begin{array}{l}\text { Family type } \\
\text { Monogamy } \\
\text { Polygyny }\end{array}$ & $\begin{array}{l}3.33(3 \quad \text { l } 08) \\
4.80\left(\begin{array}{l}1 \\
782\end{array}\right)\end{array}$ & $\begin{array}{l}\text { Family type } \\
\text { Monogamy } \\
\text { Polygyny }\end{array}$ & 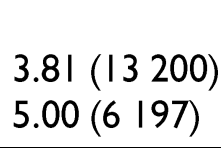 \\
\hline $\begin{array}{l}\text { Ethnicity } \\
\text { Fulfude/ Peul } \\
\text { Gourmatche } \\
\text { Mossi } \\
\text { Senoufo } \\
\text { Others } \\
\text { - } \\
\end{array}$ & $\begin{array}{l}4.32(983) \\
4.45(872) \\
3.95(5319) \\
4.01(457) \\
3.97(2713) \\
-\end{array}$ & $\begin{array}{l}\text { Ethnicity } \\
\text { Madinka/Jahanka } \\
\text { Wollof } \\
\text { Jola/Karoninka } \\
\text { Fula/Tukulur/Lorobo } \\
\text { Serahuleh } \\
\text { Others }\end{array}$ & $\begin{array}{l}4.02(1 \mathrm{l} 682) \\
3.76(677) \\
3.80(458) \\
4.05(1213) \\
3.50(384) \\
3.31(685)\end{array}$ & $\begin{array}{l}\text { Ethnicity } \\
\text { Hausa/Fulani } \\
\text { Igbo/lbo } \\
\text { Yoruba } \\
\text { Others } \\
\text { - } \\
-\end{array}$ & $\begin{array}{l}4.68(8 \quad 6 I I) \\
3.8 I(2 \text { I } 02) \\
3.28(2 \text { 42I) } \\
4.05(6 \quad 880) \\
- \\
-\end{array}$ \\
\hline
\end{tabular}

In Table 3, analysis of the individual and household characteristics showed that fertility was highest at age 35years + which is consistent for all the three countries. Across the three countries, women who got married below 18 years and had their first birth at that same age had a higher number of children than their counterparts in older age categories. Higher fertility was reported among women with no education, dwell in rural residences, poor, and not exposed to media. Finally, higher fertility was reported among women that were not involved in decision making. This is also obvious across the three countries under study.

Table 3: Mean differences of lifetime fertility by individual characteristics in Burkina Faso, Gambia, and Nigeria

\begin{tabular}{|c|c|c|c|}
\hline \multirow[t]{2}{*}{ Background Variables } & Burkina Faso & Gambia & Nigeria \\
\hline & Weighted Mean $(\mathrm{N})$ & Weighted Mean (N) & Weighted Mean (N) \\
\hline $\begin{array}{l}\text { Age } \\
15-24 \text { years } \\
25-34 \text { years } \\
35+\text { years }\end{array}$ & $\begin{array}{l}1.73(2955) \\
3.86(4763) \\
6.84(2626)\end{array}$ & $\begin{array}{l}\text { I.75 (I 329) } \\
3.67(2 \text { 499) } \\
6.48 \text { (I } 27 \text { I) }\end{array}$ & $\begin{array}{l}1.86(4996) \\
3.87(9514) \\
6.72(5504)\end{array}$ \\
\hline $\begin{array}{l}\text { Age at marriage } \\
<18 \text { years } \\
18-24 \text { years } \\
25 \text { years }\end{array}$ & $\begin{array}{l}4.28(6049) \\
3.72(4054) \\
3.08(241) \\
\end{array}$ & $\begin{array}{l}4.34(2534) \\
3.43(2201) \\
2.88(364) \\
\end{array}$ & $\begin{array}{l}4.7 \mid \text { (II 69I) } \\
3.64(6 \text { 60I) } \\
2.92(I 722) \\
\end{array}$ \\
\hline $\begin{array}{l}\text { Age at first birth } \\
<18 \text { years } \\
18-24 \text { years } \\
25 \text { years }\end{array}$ & $\begin{array}{l}4.5 \mathrm{I}(34 \mathrm{II}) \\
3.85(638 \mathrm{I}) \\
3.0 \mathrm{I}(552)\end{array}$ & $\begin{array}{l}4.75(1 \text { 694) } \\
3.53(2854) \\
2.73(55 I) \\
\end{array}$ & $\begin{array}{l}4.91(7910) \\
3.92(9595) \\
2.97(2509) \\
\end{array}$ \\
\hline
\end{tabular}




\begin{tabular}{|c|c|c|c|}
\hline $\begin{array}{l}\text { Education } \\
\text { No education } \\
\text { Primary } \\
\text { Secondary+ }\end{array}$ & 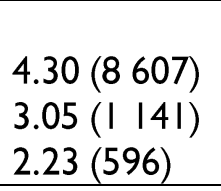 & $\begin{array}{l}4.38 \text { (3 039) } \\
3.63(711) \\
2.57(1 \text { 349) } \\
\end{array}$ & $\begin{array}{l}4.80(9779) \\
4.57(3842) \\
3.09(6393) \\
\end{array}$ \\
\hline $\begin{array}{l}\text { Wealth status } \\
\text { Poor } \\
\text { Average } \\
\text { Rich }\end{array}$ & $\begin{array}{l}4.52(4) 17) \\
4.05(2 \quad 216) \\
3.53(3 \quad 911) \\
\end{array}$ & $\begin{array}{l}4.18(2072) \\
3.96(1032) \\
3.29(1995)\end{array}$ & $\begin{array}{l}4.68(9 \quad 180) \\
4.24(3 \quad 749) \\
3.52(7 \quad 085)\end{array}$ \\
\hline $\begin{array}{l}\text { Residence } \\
\text { Urban } \\
\text { Rural }\end{array}$ & $\begin{array}{l}3.26(1911) \\
4.26(8433)\end{array}$ & $\begin{array}{l}3.40(2496) \\
4.12(2603)\end{array}$ & $\begin{array}{l}3.79(7087) \\
4.38(12927)\end{array}$ \\
\hline $\begin{array}{l}\text { Religion } \\
\text { No religion } \\
\text { Christianity } \\
\text { Islam } \\
\text { Traditionalist } \\
\end{array}$ & $\begin{array}{l}4.47(127) \\
3.92(2797) \\
3.96(6584) \\
4.72(836) \\
\end{array}$ & $\begin{array}{l}- \\
3.87(4995) \\
3.57(102) \\
7.17(2) \\
\end{array}$ & $\begin{array}{l}- \\
3.74(7293) \\
4.47(12405) \\
4.84(316) \\
\end{array}$ \\
\hline $\begin{array}{l}\text { Decision making } \\
\text { Woman involved } \\
\text { Women not involved }\end{array}$ & 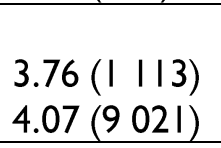 & $\begin{array}{l}3.93(1 \quad 870) \\
3.87(3 \quad 020)\end{array}$ & $\begin{array}{l}3.88(5625) \\
4.32(13772)\end{array}$ \\
\hline $\begin{array}{l}\text { Media exposure } \\
\text { Yes } \\
\text { No }\end{array}$ & $\begin{array}{l}3.96(7498) \\
4.20(2846)\end{array}$ & $\begin{array}{l}3.84(4576) \\
4.09(523)\end{array}$ & $\begin{array}{l}3.97(13391) \\
4.60(6613)\end{array}$ \\
\hline
\end{tabular}

Multivariate analysis presented in Tables 4 and 5 displayed the extent of the relationship between the independent and outcome variables. The first Model in Table 4 showed the relationship between the key explanatory variables (family type and ethnicity) and the outcome variable (LF). Model 2 in Table 5 presented the adjusted Poisson Regression analysis and $95 \%$ confidence interval of the effects of family type and ethnicity on fertility while other variables are held constant. Result in model I showed a consistent significant relationship between lifetime fertility and family type. Consistently across the three countries, lifetime fertility in polygyny family type is
29 percent, 46 percent, and 25 percent higher than that of monogamy family setting. In Burkina Faso, lifetime fertility was at least 2 percent lesser in the entire ethnic groups than among their counterparts in Mossi. In Gambia, reported lifetime fertility was significantly 10 percent and 16 percent lower in Wollof and Serahuleh than among their counterparts in Madinka/Jahanka (reference category). In Nigeria, lifetime fertility was significantly higher among the Hausa/Fulani (reference category) but more than 10 percent lesser among women in lgbo/lbo and Yoruba ethnic groups.

Table 4: Unadjusted poisson regression models showing the relationship between lifetime fertility, Family Type and Ethnicity.

\begin{tabular}{|c|c|c|c|c|}
\hline \multicolumn{5}{|l|}{ BURKINA FASO } \\
\hline $\begin{array}{l}\text { Explanatory } \\
\text { variables }\end{array}$ & IRR (CEB) & t- statistic & $P$ value & $\begin{array}{l}\text { Confidence } \\
\text { Interval }\end{array}$ \\
\hline $\begin{array}{l}\text { Family type } \\
\text { Polygyny }\end{array}$ & 1.29 & 17.45 & $\mathrm{P}<0.00 \mathrm{I}$ & $1.26-1.33$ \\
\hline $\begin{array}{l}\text { Ethnicity } \\
\text { Gourmatche } \\
\text { Mossi } \\
\text { Senoufo } \\
\text { others }\end{array}$ & $\begin{array}{l}0.98 \\
0.88 \\
0.87 \\
0.91\end{array}$ & $\begin{array}{l}-0.49 \\
-0.99 \\
-3.29 \\
-3.31 \\
\end{array}$ & $\begin{array}{l}\text { ns } \\
P<0.001 \\
P<0.05 \\
P<0.05\end{array}$ & $\begin{array}{l}0.92-1.05 \\
0.84-0.92 \\
0.81-0.95 \\
0.86-0.96\end{array}$ \\
\hline \multicolumn{5}{|c|}{$\begin{array}{l}\text { Population size }=10 \quad 133 \quad \text { Desig } \\
\text { significant }\end{array}$} \\
\hline \multicolumn{5}{|l|}{ GAMBIA } \\
\hline $\begin{array}{l}\text { Explanatory } \\
\text { variables }\end{array}$ & IRR (CEB) & t- statistic & $P$ value & $\begin{array}{l}\text { Confidence } \\
\text { Interval }\end{array}$ \\
\hline
\end{tabular}




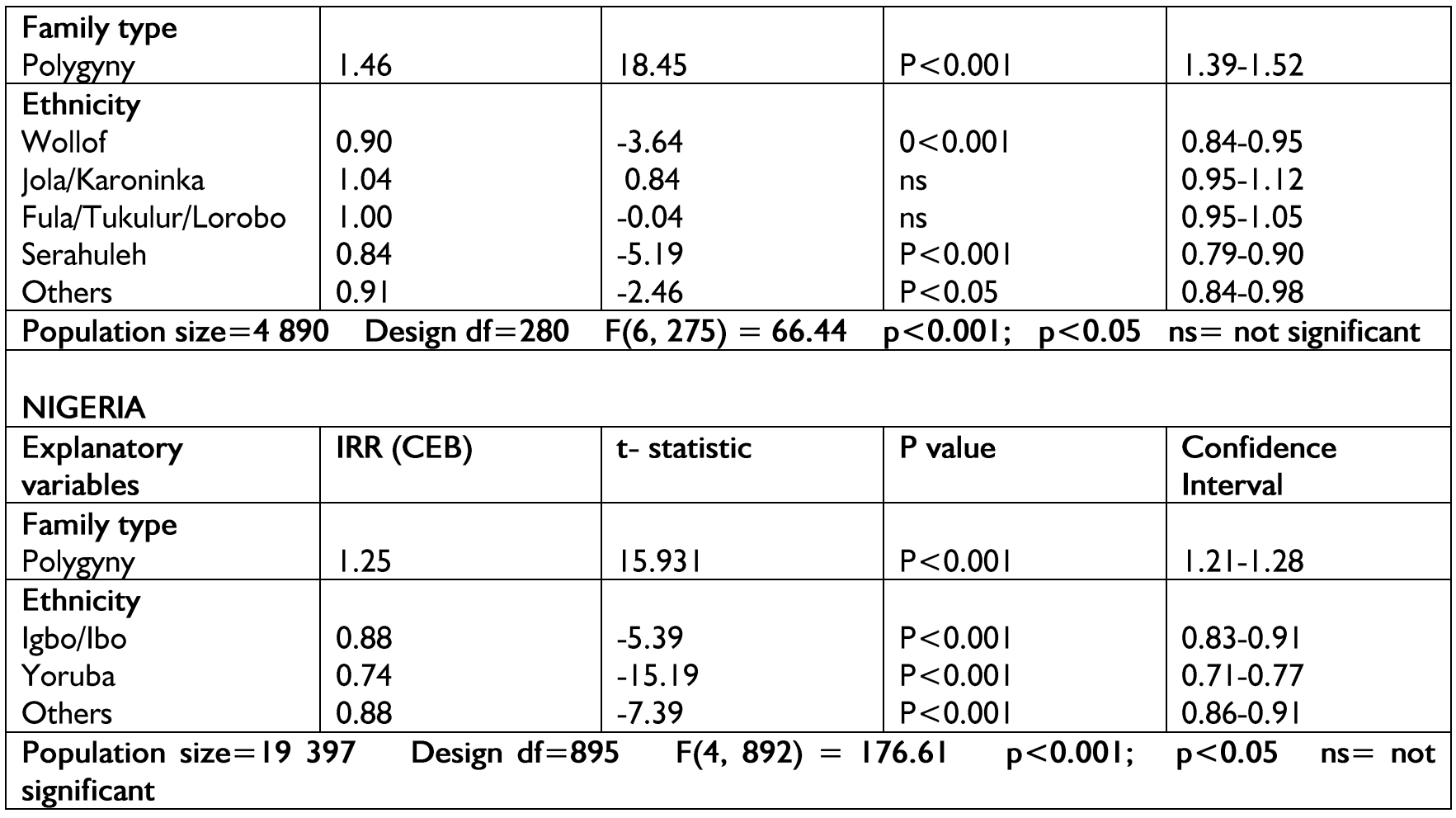

In Table 5, lifetime fertility is significantly higher in polygyny family type than those in the monogamy family (reference category). Results showed that across the three countries, lifetime fertility increased by at least 2 percent in the polygamous family than in the reference category. With respect to respondents' ethnicity, women from Gourmatche and Senoufu in Burkina Faso had 5 percent and 2 percent higher risk of having higher fertility than other ethnics. Consequently, women from Fula/Tukulur/Lorobo and Serahuleh in Gambia and from Yoruba in Nigeria had a lesser risk of having higher fertility than their counterparts in other ethnic groups. However, lgbo/lbo women were 6 percent more likely to have higher lifetime fertility than the Hausa/Fulani (RC).
On other selected variables, the result showed that fertility was more than 2 points higher among women in ages 25-34 years and 35years+ than those between ages 15-24 years for the selected countries. Age at marriage and at first birth also showed a significant influence on lifetime fertility. Analysis revealed that women who got married and delivered their first birth above 18 years were at lesser risk of having high fertility than their counterparts at the very younger group ( $<18$ years). Higher educational attainment and wealth status levels reduced the risk of having higher lifetime fertility. In addition, rural dwellers in Burkina Faso were at II percent risk of having higher lifetime fertility than women in the urban areas.

Table 5: Adjusted poisson regression models showing the relationship between lifetime fertility, family type and ethnicity.

\begin{tabular}{|c|c|c|c|c|}
\hline \multicolumn{5}{|l|}{ GAMBIA } \\
\hline Variables & IRR & t- statistic & $P$ value & $\begin{array}{l}\text { Confidence } \\
\text { Interval (Cl) }\end{array}$ \\
\hline $\begin{array}{l}\text { Family Type } \\
\text { Polygyny }\end{array}$ & 1.03 & 4.20 & $\mathrm{p}<0.001$ & $1.02-1.05$ \\
\hline $\begin{array}{l}\text { Ethnicity } \\
\text { Gourmatche } \\
\text { Mossi } \\
\text { Senoufu } \\
\text { Others }\end{array}$ & $\begin{array}{l}1.05 \\
0.98 \\
1.02 \\
0.99\end{array}$ & $\begin{array}{l}2.59 \\
-1.25 \\
0.72 \\
-0.78\end{array}$ & $\begin{array}{l}\mathrm{p}<0.05 \\
\text { ns } \\
\text { ns } \\
\text { ns }\end{array}$ & $\begin{array}{l}1.01-1.10 \\
0.95-1.01 \\
0.97-1.08 \\
0.95-1.02\end{array}$ \\
\hline $\begin{array}{l}\text { Age } \\
25-34 \text { years } \\
35 \text { years }+\end{array}$ & $\begin{array}{l}2.33 \\
4.16 \\
\end{array}$ & $\begin{array}{l}75.26 \\
124.35 \\
\end{array}$ & $\begin{array}{l}p<0.001 \\
p<0.001\end{array}$ & $\begin{array}{l}2.28-2.38 \\
4.07-4.26 \\
\end{array}$ \\
\hline $\begin{array}{l}\text { Age at marriage } \\
\text { 18-24 years } \\
25 \text { years }+\end{array}$ & $\begin{array}{l}0.89 \\
0.82\end{array}$ & $\begin{array}{l}-12.35 \\
-5.71\end{array}$ & $\begin{array}{l}p<0.001 \\
p<0.001\end{array}$ & $\begin{array}{l}0.87-0.91 \\
0.76-0.87\end{array}$ \\
\hline
\end{tabular}

http://aps.journals.ac.za 


\begin{tabular}{|c|c|c|c|c|}
\hline $\begin{array}{l}\text { Age at first birth } \\
18-24 \text { years } \\
25 \text { years }+\end{array}$ & $\begin{array}{l}0.84 \\
0.58\end{array}$ & $\begin{array}{l}-18.59 \\
-20.42 \\
\end{array}$ & $\begin{array}{l}p<0.001 \\
p<0.001\end{array}$ & $\begin{array}{l}0.82-0.86 \\
0.55-0.61 \\
\end{array}$ \\
\hline $\begin{array}{l}\text { Education } \\
\text { Primary } \\
\text { Secondary+ }\end{array}$ & $\begin{array}{l}0.93 \\
0.79\end{array}$ & $\begin{array}{l}-5.68 \\
-10.96\end{array}$ & $\begin{array}{l}\mathrm{p}<0.001 \\
\mathrm{p}<0.001\end{array}$ & $\begin{array}{l}0.90-0.95 \\
0.76-0.82\end{array}$ \\
\hline $\begin{array}{l}\text { Wealth status } \\
\text { Average } \\
\text { Rich }\end{array}$ & $\begin{array}{l}0.95 \\
0.93\end{array}$ & $\begin{array}{l}-4.96 \\
-6.94\end{array}$ & $\begin{array}{l}p<0.001 \\
p<0.001\end{array}$ & $\begin{array}{l}0.93-0.97 \\
0.91-0.95\end{array}$ \\
\hline $\begin{array}{l}\text { Residence } \\
\text { Rural }\end{array}$ & 1.11 & 7.37 & $\mathrm{p}<0.001$ & I.08-I.14 \\
\hline $\begin{array}{l}\text { Religion } \\
\text { Christianity } \\
\text { Islam } \\
\text { Traditionalist } \\
\end{array}$ & $\begin{array}{l}1.00 \\
1.01 \\
1.02 \\
\end{array}$ & $\begin{array}{l}0.02 \\
0.40 \\
0.81\end{array}$ & $\begin{array}{l}\text { ns } \\
\text { ns } \\
\text { ns }\end{array}$ & $\begin{array}{l}0.95-I .05 \\
0.96-1.06 \\
0.97-I .08 \\
\end{array}$ \\
\hline $\begin{array}{l}\text { Decision making } \\
\text { Woman not involved }\end{array}$ & 1.01 & 0.49 & Ns & $0.98-1.03$ \\
\hline $\begin{array}{l}\text { Media exposure } \\
\text { No }\end{array}$ & 0.99 & -0.40 & Ns & $0.98-1.01$ \\
\hline $\begin{array}{l}\text { Population size }=10 \quad 132 \\
\text { significant }\end{array}$ & Design $\mathrm{df}=572$ & $F(2 I, 552)=948$ & $\mathrm{p}<0$. & $<0.05 \quad n s=$ no \\
\hline \multicolumn{5}{|l|}{ GAMBIA } \\
\hline Variables & IRR & t- statistic & $P$ value & $\begin{array}{l}\text { Confidence } \\
\text { Interval (Cl) }\end{array}$ \\
\hline $\begin{array}{l}\text { Family Type } \\
\text { Polygyny }\end{array}$ & 1.06 & 3.65 & $p<0.001$ & $1.02-1.08$ \\
\hline $\begin{array}{l}\text { Ethnicity } \\
\text { Wollof } \\
\text { Jola/Karoninka } \\
\text { Fula/Tukulur/Lorobo } \\
\text { Serahuleh } \\
\text { Others }\end{array}$ & $\begin{array}{l}0.96 \\
1.02 \\
0.96 \\
0.93 \\
0.94 \\
\end{array}$ & $\begin{array}{l}-1.56 \\
0.65 \\
-2.50 \\
-2.46 \\
-2.10 \\
\end{array}$ & $\begin{array}{l}\text { ns } \\
\text { ns } \\
p<0.05 \\
p<0.05 \\
p<0.05\end{array}$ & $\begin{array}{l}0.92-1.01 \\
0.96-1.08 \\
0.92-0.99 \\
0.88-0.99 \\
0.89-0.99 \\
\end{array}$ \\
\hline $\begin{array}{l}\text { Age } \\
25-34 \text { years } \\
35 \text { years }+\end{array}$ & $\begin{array}{l}2.26 \\
3.83\end{array}$ & $\begin{array}{l}37.02 \\
70.33\end{array}$ & $\begin{array}{l}p<0.001 \\
p<0.001\end{array}$ & $\begin{array}{l}2.16-2.35 \\
3.69-3.97\end{array}$ \\
\hline $\begin{array}{l}\text { Age at marriage } \\
18-24 \text { years } \\
25 \text { years }+\end{array}$ & $\begin{array}{l}0.89 \\
0.84\end{array}$ & $\begin{array}{l}-5.53 \\
-3.68 \\
\end{array}$ & $\begin{array}{l}p<0.001 \\
p<0.001\end{array}$ & $\begin{array}{l}0.86-0.93 \\
0.76-0.92 \\
\end{array}$ \\
\hline $\begin{array}{l}\text { Age at first birth } \\
18-24 \text { years } \\
25 \text { years }+\end{array}$ & $\begin{array}{l}0.80 \\
0.53\end{array}$ & $\begin{array}{l}-13.15 \\
-14.96 \\
\end{array}$ & $\begin{array}{l}\mathrm{p}<0.001 \\
\mathrm{p}<0.001\end{array}$ & $\begin{array}{l}0.77-0.83 \\
0.49-0.58\end{array}$ \\
\hline $\begin{array}{l}\text { Education } \\
\text { Primary } \\
\text { Secondary+ }\end{array}$ & $\begin{array}{l}0.95 \\
0.87\end{array}$ & $\begin{array}{l}-2.33 \\
-4.47 \\
\end{array}$ & $\begin{array}{l}p<0.001 \\
p<0.001\end{array}$ & $\begin{array}{l}0.91-0.99 \\
0.82-0.92 \\
\end{array}$ \\
\hline $\begin{array}{l}\text { Wealth status } \\
\text { Average } \\
\text { Rich }\end{array}$ & $\begin{array}{l}0.98 \\
0.95\end{array}$ & $\begin{array}{l}-0.81 \\
-2.06 \\
\end{array}$ & $\begin{array}{l}\text { ns } \\
\mathrm{p}<0.05\end{array}$ & $\begin{array}{l}0.95-1.02 \\
0.90-0.99 \\
\end{array}$ \\
\hline $\begin{array}{l}\text { Residence } \\
\text { Rural } \\
\end{array}$ & 1.05 & 1.74 & Ns & $0.99-1.10$ \\
\hline $\begin{array}{l}\text { Religion } \\
\text { Islam } \\
\text { Traditionalist } \\
\end{array}$ & $\begin{array}{l}1.02 \\
1.43 \\
\end{array}$ & $\begin{array}{l}0.44 \\
5.43\end{array}$ & $\begin{array}{l}\text { ns } \\
p<0.001\end{array}$ & $\begin{array}{l}0.93-1.12 \\
1.26-1.63 \\
\end{array}$ \\
\hline $\begin{array}{l}\text { Decision making } \\
\text { Woman not involved }\end{array}$ & 1.01 & 0.57 & Ns & $0.98-1.04$ \\
\hline
\end{tabular}




\begin{tabular}{|c|c|c|c|c|}
\hline $\begin{array}{l}\text { Media exposure } \\
\text { No }\end{array}$ & 0.97 & -1.16 & Ns & $0.93-1.02$ \\
\hline Population size $=4889$ & Design $\mathrm{df}=\mathbf{2 8 0}$ & $F(2 I, 552)=444$ & $p<0.001 ; p<0.05$ & ns $=$ not significant \\
\hline \multicolumn{5}{|l|}{ NIGERIA } \\
\hline Variables & IRR & t- statistic & $P$ value & $\begin{array}{l}\text { Confidence } \\
\text { Interval (Cl) } \\
\end{array}$ \\
\hline $\begin{array}{l}\text { Family Type } \\
\text { Polygyny }\end{array}$ & 1.02 & 2.95 & $p<0.05$ & $1.01-1.04$ \\
\hline $\begin{array}{l}\text { Ethnicity } \\
\text { Igbo/lbo } \\
\text { Yoruba } \\
\text { Others }\end{array}$ & $\begin{array}{l}1.06 \\
0.89 \\
0.92\end{array}$ & $\begin{array}{l}3.03 \\
-7.52 \\
-2.29\end{array}$ & $\begin{array}{l}p<0.05 \\
p<0.001 \\
p<0.05\end{array}$ & $\begin{array}{l}1.02-1.10 \\
0.86-0.92 \\
0.95-1.00\end{array}$ \\
\hline $\begin{array}{l}\text { Age } \\
25-34 \text { years } \\
35 \text { years }+\end{array}$ & $\begin{array}{l}2.36 \\
4.26\end{array}$ & $\begin{array}{l}82.32 \\
128.62\end{array}$ & $\begin{array}{l}p<0.001 \\
p<0.001\end{array}$ & $\begin{array}{l}2.31-2.41 \\
4.17-4.36 \\
\end{array}$ \\
\hline $\begin{array}{l}\text { Age at marriage } \\
\text { I } 8 \text { - } 24 \text { years } \\
25 \text { years }+\end{array}$ & $\begin{array}{l}0.90 \\
0.80\end{array}$ & $\begin{array}{l}-10.79 \\
-10.37\end{array}$ & $\begin{array}{l}p<0.001 \\
p<0.001\end{array}$ & $\begin{array}{l}0.89-0.92 \\
0.77-0.84\end{array}$ \\
\hline $\begin{array}{l}\text { Age at first birth } \\
18-24 \text { years } \\
25 \text { years }+\end{array}$ & $\begin{array}{l}0.79 \\
0.54\end{array}$ & $\begin{array}{l}-30.26 \\
-35.96\end{array}$ & $\begin{array}{l}p<0.001 \\
p<0.001\end{array}$ & $\begin{array}{l}0.78-0.80 \\
0.53-0.56\end{array}$ \\
\hline $\begin{array}{l}\text { Education } \\
\text { Primary } \\
\text { Secondary+ } \\
\end{array}$ & $\begin{array}{l}1.00 \\
0.89\end{array}$ & $\begin{array}{l}0.69 \\
-9.77\end{array}$ & $\begin{array}{l}\mathrm{ns} \\
\mathrm{p}<0.001\end{array}$ & $\begin{array}{l}0.99-1.02 \\
0.87-0.91 \\
\end{array}$ \\
\hline $\begin{array}{l}\text { Wealth status } \\
\text { Average } \\
\text { Rich }\end{array}$ & $\begin{array}{l}0.98 \\
0.96\end{array}$ & $\begin{array}{l}-1.76 \\
-3.66\end{array}$ & $\begin{array}{l}\text { ns } \\
\mathrm{p}<0.001\end{array}$ & $\begin{array}{l}0.96-1.00 \\
0.94-0.98\end{array}$ \\
\hline $\begin{array}{l}\text { Residence } \\
\text { Rural }\end{array}$ & 0.99 & -1.30 & Ns & $0.97-1.01$ \\
\hline $\begin{array}{l}\text { Religion } \\
\text { Islam } \\
\text { Traditionalist }\end{array}$ & $\begin{array}{l}1.01 \\
1.05\end{array}$ & $\begin{array}{l}1.02 \\
1.62\end{array}$ & $\begin{array}{l}\text { ns } \\
\text { ns }\end{array}$ & $\begin{array}{l}0.99-I .04 \\
0.99-I .|I|\end{array}$ \\
\hline $\begin{array}{l}\text { Decision making } \\
\text { Woman not involved }\end{array}$ & 1.02 & 1.90 & Ns & $0.99-1.03$ \\
\hline $\begin{array}{l}\text { Media exposure } \\
\text { No }\end{array}$ & 1.01 & 1.58 & Ns & $0.99-1.03$ \\
\hline $\begin{array}{l}\text { Population size }=19390 \\
\text { significant }\end{array}$ & Design $\mathrm{df}=8$ & $F(2 I, 552)$ & $\mathrm{p}<0.00 \mathrm{I}$ & $<0.05$ ns $=$ not \\
\hline
\end{tabular}

\section{Discussion of findings}

This study examined the effects of family type and ethnicity on lifetime fertility in three West African countries. Findings in all the three selected countries showed that the number of children born to women in polygyny family settings is higher than those born to women in a monogamy family setting. Similar findings were reported by James and Isiugo-Abanihe (2010) in their study on adolescents' family size preference and Asa et al, (2016) in their study on assessment of contraceptive use by marriage type among sexually active men in Nigeria. The authors found that that the likelihood of large family size preference is significantly higher among polygyny family type compared with the monogamy family setting. This finding is not surprising vis-à-vis practices http://aps.journals.ac.za in the polygyny family setting where the pro-natalist attitudes still prevail and where there is unhealthy competition among wives to have more male children or higher number of children that will inherit the father's properties. In addition to this, traditionally, socio-cultural values and norms in many African communities support and celebrate many children. In fact, in some communities, special titles are given to the man with the highest number of children. As a result, men see marrying more than one wife as a means of increasing his number of children whether for economic benefits or for societal tittle/recognition.

Ethnic groups have different traditions, values, norms, cultures, dialects, and sacred practices, which could influence fertility level. Thus, the study found 
wide ethnic variations in fertility. The highest fertility was observed only in Gourmatche in Burkina Faso. Previous studies by Caldwell and Caldwell (1989) and Caldwell, Orubuloye, and Caldwell (1992) have established that high fertility-related cultural practices are common among different ethnic groups in African countries. High-level of social interactions in some communities particularly the heterogeneous communities and the existence of norms that support high fertility could influence fertility level.

In Gambia, lower fertility was observed in Serahuleh while in Nigeria, lower fertility rates were observed among the Igbo/lbo and Yoruba ethnics. The lower fertility in these ethnic groups could stem from the fact that more than half of the population in these ethnic groups belongs to urban settings (NPC and ICF International, 20I4) which lead to better education and exposure to knowledge and practice of contraception as a tool for controlling births. As a result, fertility in these ethnic groups happens to be lower than other ethnic groups. For instance, in Nigeria, the practice of polygyny and high fertilityrelated cultural practices are more prevalent among the Hausa/Fulani tribes. The majority of women from these tribes, usually the Muslims dominated the northern part of the country are usually uneducated, married at a younger age, do not embrace contraceptive use, do not have a say in fertility decision-making, and lack information on family planning methods and services. Thus, they are unaware of the different contraceptive methods even if they desire to control their family size.

Further, the study found that age at marriage was significantly associated with lifetime fertility. Women who married at older ages have low lifetime fertility. This finding corroborates other studies elsewhere (Acharya, 20l0; Adhikari, 20l0; Nahar et al., 20l3). This may be attributed to the fact that childbearing is socially acceptable within marriage and women who marry early have on average, longer exposure to the risk of pregnancy while those who marry lately have shorter exposure to pregnancy. Hence, low lifetime fertility is expected among women who married at older ages. The finding may also be attributed to female educational level, social and economic empowerment, and maternal health information.

The age at which childbearing begins is a crucial determinant of lifetime fertility. The risk of becoming pregnant often declines with age and delays in first births. As a result, an increase in age at marriage reduces lifetime fertility. This study found a significant relationship between age at first birth and lifetime fertility. Across the three selected countries, women who had their first birth in older age groups were less likely to have a higher number of children than those in the very young group of below 18 years. This finding is in line with Oyefara (20I I) who put forward that higher number of births tends to be reported among women who give birth at the very early age of below 20 years than among those in the older ages. This finding is expected because childbearing at an early age increases a woman's chances of giving birth to more children before getting to the very older ages.

The study also found a significant association between wealth status of women and lifetime fertility. This finding corresponds with the previous study by Institute of Family Studies (20/3) and Skirbekk (2008) where it was found that lesser number of children was delivered by women in higher wealth quintile than their counterparts who are poor. In Africa, more than $40 \%$ of the women live below poverty level (United Nations, 20I5). Wealthy women have better access to education which thereafter increases their knowledge and exposure to family planning information and services. This, in turn, affects their perception and behavior their fertility wants. In addition to this, use of contraceptives and aspiring for a better life may have influenced the rich women to have a smaller number of children.

The study further found that differentials in fertility are substantial and are inversely related to educational attainment of women. Women with primary and secondary education and above had a lesser risk of having many children than those with no education at all. This finding corroborates the studies of Bbaale and Mpuga (20II) and Adebowale and Palamuleni (2014) who opined that more educated women who had secondary and post-secondary education tend to have fewer children. This finding is expected and could be as a result of the women's exposure and knowledge about contraceptives, exposure to reproductive health risks as well as the economic burden and child investment.

\section{Conclusion and recommendations}

Our study acknowledged that family type and ethnicity are important factors in explaining lifetime fertility in the three selected West African countries. The study identified high lifetime fertility among women in polygyny family settings among Gourmatche in Burkina Faso, Fula in Gambia and Hausa/Fulani in Nigeria ethnic groups. This result suggests the need for effective policy, program and research interventions that will educate men and women to drop their pro-natalist attitudes even though it is difficult but necessary. Cultural practices that promote high fertility, many wives and preference for a particular sex, among others should be addressed. The study also linked age at marriage, age at first birth, wealth status, and educational

http://aps.journals.ac.za 
attainment of women to high lifetime fertility. This finding, therefore, suggests the need for effective policy interventions to raise average age at first marriage, and age at first birth by investing in women education, employment and empowerment in order to reduce lifetime fertility. Also, governments and other stakeholders should promote and involve men in family planning, decision making and the use of contraceptives. Finally, governments need to focus on job creation to reduce the poverty level, one of the pre-conditions for reducing high fertility rates in developing countries, particularly in sub-Saharan Africa.

\section{Acknowledgements}

Authors gratefully acknowledge the supports and comments from the 2016 Family Demography in African and Post-2015 Development Agenda Conference, hosted by Demography and Population Studies and co-sponsored by the NRF CoE in Human Development, NRF Conference Fund, and National Institute for Humanities and Social Sciences, South Africa. Also, Authors are grateful to ICF International for the DHS data.

\section{Authors' contributions}

All authors contributed extensively to the work presented in this paper particularly in the analysis, discussion of the results and critical revision of the final manuscript. B.O., O.B. and J.K. conceived and planned the article. B.O., J.K and B.S. interpreted the data and drafted the article.

\section{References}

Acharya, A. K. (2010). The Influence of Female Age at Marriage on Fertility and Child Loss in India. Trajectories, 12(31): 6I-80.

Adebowale, A. A. and Palamuleni, M. E. (20|4). Childbearing Dynamics among Married Women of Reproductive Age in Nigeria: Re-affrming the Role of Education. African Population Studies, 27(2): 30I-3I8.

Adebowale, S. A., and Palamuleni, M. E. (2015). Influence of Gender Preference and Sex Composition of Surviving Children on Childbearing Intention among High Fertility Married Women in Stable Union in Malawi. Afr Health Sci, I5(I): I50-60.

Adhikari, R. (2010). Demographic, Socio-economic and Cultural Factors Affecting Fertility Differentials in Nepal. BMC Pregnancy and Childbirth, IO(19): I-II.

Akintunde, M. O., Lawal, M. O. and Simeon, O. (20|3). Religious Roles in Fertility Behaviour among the Residents of Akinyele Local Government, Oyo State, Nigeria. International
Journal of Economy, Management, and Social Sciences, 2(6): 455-4.

Alonge, S. K., and Ajala, A. O. (20/3). Fertility Behaviour and Women's Empowerment in Oyo State. Journal of Economics and Sustainable Development, 4(I8): 33-4I.

Alonzo, R., Balisacan, A., Canlas, D et al (2004). Population and Poverty: The Real Score. University of the Philippines, School of Economics. Discussion $\quad 4 / 5$. http://www.econ.upd.edu.ph/respub/dp/pdf/.

Accessed on 24th March, 2017.Asamoah, B., Agardh, A. and Ostergren, P. (2013). Inequality in Fertility Rate and Modern Contraceptive Use among Ghanaian Women from 1988-2008. Int J Equity Health, 12:37.05.

Barnes, J. A. (1970). Marriage in Changing Society: A Study in Structural Change among the Fort Jameson Ngoni. The Rhodes-Livingstone Papers, Manchester: Manchester University Press, I95I, 1970.

Basu, A. M. (2002). Why does Education Lead to Low Fertility? a Critical Review of some of the Possibilities. World Development, 30(10): 17791790.

Bauni, E., Gichuhi, W. and Wasao, S. (2002). Ethnicity and Fertility in Kenya. Working Paper No. II. APHRC.

Bbaale, M. and Mpuga, P. (20I I). Female Education, Contraceptive Use, and Fertility: Evidence from Uganda. The Journal of Sustainable Development, 6(I): 20-47.

Becker G. S. (1960). "An Economic Analysis of Fertility." In: Becker GS, editor. Demographic and Economic Change in Developed Countries. Princeton, NJ: Princeton University Press; pp. 135-87. Having People. Population and Development Review, 30(2): 22I-234.

Bongaarts, J. (2002). The End of the fertility transition in the Developing World. Paper Presented to the Expert Meeting on Completing the Fertility Transition, United Nations- Population Division, New York, USA. http://www.un.org/esa/population/publicatio/com pleting fertility/RevisedBONGAARTSpaper.PDF. Accessed on 24th March, 2017.

Bongaarts, J. (2006). The Causes of stalling Fertility Transitions. Studies in Family Planning, 37(1): I16.

Burkina Faso Standard DHS (2003). Institute National de la Statistique et de la Demographie, Ministere de L'Economie et du Development, Ouagadougou, Burkina Faso, and ORC Macro, Calverton, MD, USA.

Caldwell, John C., I. O. Orubuloye, and Pat Caldwell. (1992). "Fertility Decline in Africa: A New Type of 
Transition?" Population and Development Review, 18: 21 I-242.

Caldwell, J. C., and Caldwell, P. (1987). The Cultural Context of high fertility in sub-Saharan Africa. Population and development Review, I3(3): 409437.

Casterline J. B., and S. W. Sinding (2000). Unmet Need for Family Planning in Developing Countries and Implications for Population Policy. Population and Development Review, 26: 4 69I-723.

Chamie, J. (1977). Religious Differentials in Fertility: Lebanon 197I. Population Studies, 3I(2): 365382.

Chaudhury, R. H. (1984). Hindu-Muslim Differential Fertility: How Much Religious and How Much Socio? Social Action, 34(3): 25I-273.

Chege, J. (2005). Interventions Linking Gender Relations and Violence with Reproductive Health and HIV: Rationale, Effectiveness, and gaps", Agenda Special Focus. http://www.populationcouncil.net/pdfs/frontiers/jo urnals/Agenda_Chege05.pdf. Accessed on 24th March, 2017.

Chondoka, Y. A. (1988). Traditional Marriages in Zambia: A Study in Cultural History, Ndola Mission Press.

Cleland, J. (2002). Education and Future Fertility Trends with Special Reference to Mid-transitional Countries in Completing the Fertility TransitionPart 2.Background Papers, 187-202. United Nations Population Division, Department of Economic and Social Affairs, New York, USA.

Dribe, M., Oris, M. and Pozzi, L. (20/4). Socioeconomic Status and Fertility Before, During, and After the Demographic Transition. Demographic Research Volume, 31(7): |6|-182.

Easterlin, R. (1969). Towards a Socio-economic Theory of Fertility: A Survey of Recent Research on Economic Factors in American Fertility. "In Fertility and Family Planning: A World View. Edited by S. J. Behrman et al, Ann Arbor: University of Michigan Press.

Egero, B. (1996). Poverty and Fertility: Reproductive Change Under Persistent Poverty. Yearbook of Population Research in Finland, 33: 21 8-242.

El-Ghannam, A. R. (2005). An Examination of Factors Affecting Fertility Rate Differentials as Compared Among Women in Less and More Developed Countries. J. Hum. Ecol, I8(3): I8I-192.

Eriksen, T.H. (1993). Ethnicity and Nationalism. First Edition. Pluto Press.

Fitaw, Y., Berhane, Y. and Worku, A. (2004). Impact of Child Mortality and Fertility Preferences on Fertility Status In Rural Ethiopia. East African Medical Journal, 8I (6): 300-306.
Gwatkin, D. R., Rustein, S., Johnson, K., Suliman, E., Wagastaff, A. and Amouzou, A. (2007). Socio-economic Differences in Health, Nutrition, and Population in Developing Countries: An Overview of Health, Nutrition and Population, Country reports on HNP and Poverty, The World Bank, Washington DC, USA.

Gyimah, S.O. (2002). Ethnicity and infant mortality in Sub-Saharan Africa: The case of Ghana. Population Studies Centre Discussion Paper, Number 02-10. The University of Western Ontario, London, Ontario, Canada.

Hindin, M. J. (2000). Women's Autonomy, Women's Status and Fertility-related Behavior in Zimbabwe. Population Research and Policy Review, 19(3): 255-282.

Hyatt, D. E., and Milne, W. J. (1993). Determinants of Fertility in Urban and Rural Kenya: Estimates and a Simulation of the Impact of Education Policy. Environment and Planning, 25(3): 37I-382.

Institut National de la Statistique et de la Démographie (INSD) et ICF International, (20I2).

Enquête Démographique et de Santé et à Indicateurs Multiples du Burkina Faso 2010. Calverton, Maryland, USA: INSD et ICF International.

Institute of family studies. (20I3). How income affects fertility. http://ifstudies.org/how-incomeaffects-fertility/. Accessed on March 25, 2016.

James, G. and Isiugo-Abanihe, C. (20।0). Adolescents' Reproductive Motivations and Family Size Preferences in North-Western Nigeria. Asian Journal of Medical Sciences, 2(5): 218-226.

Bongaarts, J. (1978). A Framework for Analysing the Proximate Determinants of Fertility. Population and Development Review, 4(I): I05- 132.

Kingsley Davis and Judith Blake (1956). Social structure and fertility: An analytic framework. Economic Development and Cultural Change 4(4): 2 I I- 235.

Komurembe, G. R. (20II). The Influence of Cultural and Gender Practices on Fertility Rates in Ruhaama County,Ntungamo District. http://hdl.handle.net/I0570/28I I. Accessed on March 24, 2016.

Kumar, A. and Kshatriya, G. (20I3). Sex Preference and Fertility: A Study among the Ansaris of Meerut District, Uttar Pradesh. Stud Home Com Sci, 7(2): I09-II 7.

LeCostaouec, N. (2006). The Effect of Religious Belief on Fertility Rates in Europe and the United States. Research Center Working Paper Series No. 10 Undergraduate Major in Politics Saint Anselm College Manchester, N.H 03I02-I 3 IO. 
Leibenstein, H. (1957). Economic Backwardness and Economic Growth. New York: John Wiley.

Mace, S. R., and lan, M. A. (2003). The effects of kin on female fertility in Rural Gambia. Evolution and Human Behavior, 24(I): 25-42.

Madsen, E. L. (20I5). What is Behind West and Central Africa's Youthful Demographics? High Desired Family Size. www.newsecuritybeat.org/2015/05/what-westcentral--africa'syouthful-demographics-high-desired-family-size/. Accessed on 3 October, 2016.

Makinwa- Adebusoye, P. (200I). Socio-cultural Factors Affecting Fertility in Sub-Saharan Africa. Workshop on Prospects for fertility decline in High Fertility Countries. Population Division. Department of Economic and Social Affairs, United Nations Secretariat, New York, No 9-II.

Martin, T. C. (1995). Women's Education and Fertility: Results from 26 Demographic and Health Surveys. Studies in Family Planning, 26(4): 187-202.

Merrick, T.W. (2002). "Population and Poverty: New Views On An Old Controversy", International Family Planning Perspectives, 28(I): 41 -46.

Mturi, A. J. (1989). Infant and Child mortality and its Effects on fertility in Kenya [M.S. thesis], Cairo Demographic Centre.

Nahar, M. Z., Zahangir, M. S. and Islam, S.M.S. (20/3). Age at First Marriage and Its Relation to Fertility in Bangladesh. Chinese Journal of Population Resources and Environment, II(3): 227-235.

National Population Commission (NPC) and ICF International. (2000). Nigeria Demographic and Health Survey 1999. Abuja, Nigeria: National Population Commission and IFC International.

National Population Commission (NPC) [Nigeria] and ICF International. (2004). Nigeria Demographic and Health Survey 2003. Abuja, Nigeria: National Population Commission and ICF Macro.

National Population Commission (NPC) and ICF International. (2009). Nigeria Demographic and Health Survey 2008. Calverton, Maryland: National Population Commission and ORC Macro.

National Population Commission (NPC) and ICF International. (20/4). Nigeria Demographic and Health Survey 2013. Abuja, Nigeria: National Population Commission and IFC International.

Odusola, A. F. (2002). Poverty and fertility Dynamics: A Micro Evidence. A Paper Presented at the Centre for the Study of African Economies of Oxford University by Head Research NCEMA,lbadan.http://www.csae.ox.ac.uk/confere
nce/2002-UPaGiSSA/papers/Odusolacase.pdf. Accessed on 24th March, 2017.

Orteba, A. J. C. (2005). Poverty, Fertility preferences and Family Planning Practice in the Philippines. Philippine Institute for Development Studies, Discussion Papers.

Oyefara, J. L. (20I I). Age at First Birth and Fertility Differentials among Women in Osun State, Nigeria. European Scientific Journal, 8(16): 139163.

Rai, P., Paudel, I., Ghimire, A., Pokharel, P., Rijal, R. and Niraula, S. (20I4). Effect of Gender Preference on Fertility: Cross-Sectional Study among Women of Tharu Community from Rural Area of Eastern Region of Nepal. Reproductive Health, I4; II(I): 15.

Reed, H. E. and Mberu, B. U. (20/4). Capitalizing on Nigeria's Demographic Dividend: reaping the Benefits and Diminishing the Burdens. African Population Studies, 27(2): 319-330.

Satyajeet, N. (2005). Cultural Determinants of Human Fertility: A Study of Tribal Population in Orissa. Anthropologist, 7(3): 221-227.

Skirbekk, V. (2008). Fertility Trends by Social Status. Demographic Research, Vol 18 (5): I45- 180.

Smith, D. J. (2004). Contradictions in Nigeria's fertility Transition: the Burdens and Benefits of Having People. Population and Development Review, 30(2): 22I-238.

Sanderson, S. K. (200I). An Evolutionary Interpretation of Fertility decline; New Evidence. Population and Environment, 22(6): 555-563.

Taylor-Thomas J. T. (1989). The Gambian National Population Policy and Programmes Developments in Family Planning Policies and Programmes in Africa. Legon, Ghana, University of Ghana, Regional Institute for Population Studies [RIPS], 505-22.

The Gambia Bureau of Statistics (GBoS) and ICF International (2014). The Gambia Demographic and Health Survey 20/3. Banjul, The Gambia, and Rockville, Maryland, USA: GBOS and ICF International.

The Gambia Bureau of Statistics [GBoS] and ICF International (20I4). Population and Housing Census 2013: Preliminary Findings. Banjul, The Gambia: Gambia Bureau of Statistics.

The World Factbook (20I2). Country Comparison: Total Fertility Rate. https://www.cia.gov/library/publications/theworld-factbook/rankorder/2 I27rank.html. Accessed on $24^{\text {th }}$ March, 2016.

Therbone, G. (2006). African Families in a Global Context. Research Report. No. |3| nordiskaafrikainstitutet. 
United Nations (20I5). The Millennium Development Goals Report. www.un.org/millenniumgoals/2015_MDG_Report /pdf/backgrounders. Accessed on $2 \overline{5}$ March, 2015.

United Nations Children's Fund (2013). The State of the World's Children: Total Fertility Rates (TFR). http://data.un.org/Data.aspx?d=SOWC\&f=inID\% $3 \mathrm{~A} I 27$. Assessed on $24^{\text {th }}$ march, 2016.

Upadhyay U. D., J. D. Gipson, M. Withers, S. Lewis, E. J. Ciaraldi, A. Fraser, M/ J. Huchko, and N. Prata (20I4), Women's empowerment and fertility: A review of the literature. Soc Sci Med. August, 0: II I-I 20.

Upadhyay, U. D., and Karasek, D. (2010). Women's Empowerment and Achievement of Desired Fertility in Sub-Saharan Africa. DHS Working Papers No. 80. Calverton, Maryland, USA: ICF Macro.

World Bank (20I I). Reproductive Health at a Glance in Burkina Faso. World Development
Indicators, WashingtonDC.www.worldbank.org/ WEBSITE/EXTERNAL/COUNTRIES/AFRICAEXT /BURKINFASOEXT/O,,menuPK:343886-pagePK

: |4 I I 32 .html. Accessed on October 12, 2016.

World Bank (2013). World Development Indicators:

Reproductive

Health

http://data.worldbank.org/indicator/SP.DYN.TFRT .IN/countries/GH-ZF-

$\mathrm{XN}$ ?display=graph. Accesses on March 24, 2016.

World Bank Indicator (20I3). Gambia - Reproductive Health: Fertility Rate - Total (births per woman) in Gambia.

http://www.tradingeconomics.com/gambia/fertility -rate-total-births-per-woman-wb-data.html. Accessed on $7^{\text {th }}$ October, 2016.

World BFertility Data (20I2).www.un.org.esa/population/publication/wf d20I $2 /$ metadata/CEB/pdf.

Accessed on October 6, 2016. 